\title{
Leptin receptor expression in fetal lung increases in late gestation in the baboon: a model for human pregnancy
}

\author{
M C Henson ${ }^{1-3,5,6}$, K F Swan ${ }^{1}$, D E Edwards ${ }^{1,5}$, G W Hoyle ${ }^{4,5}$, J Purcell ${ }^{6}$ \\ and V D Castracane \\ Departments of ${ }^{1}$ Obstetrics and Gynecology, ${ }^{2}$ Physiology, ${ }^{3}$ Structural and Cellular Biology and ${ }^{4}$ Medicine, \\ ${ }^{5}$ Interdisciplinary Program in Molecular and Cellular Biology and ${ }^{6}$ Tulane National Primate Research Center, \\ Tulane University Health Sciences Center, New Orleans, Louisiana 70112, USA and ${ }^{7}$ Department of Obstetrics \\ and Gynecology, Texas Tech University Health Sciences Center, Amarillo, Texas 79106, USA
}

Correspondence should be addressed to M C Henson, Department of Obstetrics and Gynecology (SL-11), Tulane University Health Sciences Center, 1430 Tulane Avenue, New Orleans, Louisiana 70112-2699, USA; Email: henson@tulane.edu

V D Castracane is now at Diagnostic Systems Laboratories, Inc., Webster, Texas 77598, USA

\begin{abstract}
Leptin produced by both adipose tissue and the placental trophoblast, has been proposed to regulate numerous aspects of human conceptus development. Although recent animal studies have suggested an additional role for the polypeptide in fetal lung maturation, no evidence has been reported in primates. Therefore, we employed the baboon (Papio sp.), a well-characterized primate model for human pregnancy, to determine the presence and ontogeny of leptin receptor in fetal lung with advancing gestation. Lungs were collected from fetal baboons, early in gestation (days 58-62, $n=4$ ), at mid gestation (days 98-102, $n=4)$, and late in gestation (days 158-165, $n=4$ ) (term 184 days). mRNA transcripts for leptin (LEP) and both long and short intracellular domain isoforms of the leptin receptor (LEP- $R_{L}$ and LEP- $\left.R_{S}\right)$ were assessed by $R T-P C R$. leptin receptor protein was evaluated by immunoblotting and cell types expressing leptin receptor were identified in late pregnancy by immunohistochemistry. Fetal serum leptin concentrations, determined by RIA, remained relatively unchanged at $5.7 \pm 1.1 \mathrm{ng} / \mathrm{ml}$ (mean \pm S.E.M.) in mid pregnancy and $8.4 \pm 3.0 \mathrm{ng} / \mathrm{ml}$ in late pregnancy $(P>0.05)$. Although leptin were detectable in fetal lung, no changes in transcript abundance were apparent with advancing gestation. However, transcripts for both LEP- $R_{L}$ and LEP- $R_{S}$ receptor isoforms increased several-fold $(P<0.05)$ in fetal lung between mid and late gestation, while leptin receptor protein was detectable only in late pregnancy. leptin receptor was localized in distal pulmonary epithelial cells, including type II pneumocytes. In conclusion, leptin is present in the fetal baboon and its receptor is enhanced during late gestation in cells responsible for the synthesis of pulmonary surfactant. Collectively, these and past findings may suggest a modulatory role for the polypeptide in pulmonary development and/or may identify leptin receptor as a physiological marker of primate fetal lung maturity.

Reproduction (2004) 127 87-94
\end{abstract}

\section{Introduction}

During human pregnancy leptin is produced by maternal and fetal adipose tissues, as well as by the placental trophoblast, and is measured in significant concentrations in the maternal, fetal and umbilical circulations (Henson \& Castracane 2000). In addition to modulating adipose stores and maintaining energy homeostasis via satiety (Friedman \& Halaas 1998, Ahima \& Flier 2000), leptin has also been implicated as a direct regulator of conceptus development. Proposed roles for this multifaceted polypeptide include regulating trophoblast invasion and endocrinology, fetal and placental growth, angiogenesis, hematopoiesis, fetal bone development, and the maturation of the fetal immune system. Indeed, acting via autocrine and/or paracrine mechanisms, leptin may be an important factor in the maintenance of pregnancy itself (Bajoria et al. 2002, Henson \& Castracane 2002, 2003, Sagawa et al. 2002).

In addition to these roles, leptin has also been associated with the regulation of pulmonary development and respiration. Thus, in the mouse, leptin receptor mRNA has been detected in the lungs of fetuses (Hoggard et al. 1997). Specific leptin-binding sites in the pulmonary parenchyma and bronchiolar epithelium bind purified radiolabeled analog and leptin receptor expression has been demonstrated between birth and adulthood (Dal Farra et al. 2000). Receptors are also expressed in both normal 
human lung and the SQ-5 human lung squamous cancer cell line. SQ-5 cell proliferation was enhanced following co-incubation with recombinant human leptin, suggesting a receptor-mediated effect (Tsuchiya et al. 1999). In the $o b / o b$ mouse, respiratory anomalies that are common with the obese phenotype (tachypnea, decreased lung compliance and aberrant respiratory muscle adaptations) were attenuated following prolonged leptin administration (Tankersley et al. 1998). Similarly, in wild-type mice that were obese merely as a consequence of their high-fat diet, respiratory depression was alleviated by leptin treatment (O'Donnell et al. 1999).

Insufficient maturation of the fetal lungs, a condition that can be characterized by the production of inadequate amounts of pulmonary surfactant by epithelial type II cells, is a leading cause of human neonatal morbidity and mortality following premature birth. In the term infant, an increase in cortisol prompts the differentiation of type II cells and consequently, surfactant synthesis (Bolt et al. 2001). However, in preterm infants, surfactant levels are insufficient and pulmonary insults lead to acute lung injury and in some cases, chronic lung disease. Surfactant production is also modulated by soluble growth factors that mediate epithelial mesenchymal interactions. In this capacity, Torday et al. (2002), reported that leptin was expressed by fibroblasts and that leptin receptor was expressed by type II cells in fetal rat lung, suggesting a paracrine signaling mechanism in developing pulmonary tissue. They later concluded that leptin plays a direct role in enhancing surfactant production (Torday \& Rehan 2002), a potential recently reiterated by Vlahakis \& Hubmayr (2003). Leptin receptor was also identified in fetal rabbit type II cells and additional evidence supported correlations between leptin, maturation of the pulmonary epithelium and surfactant production (Bergen et al. 2002). Evidence associating leptin with human pulmonary development has yet to be reported, necessitating the need for the current study, which to the best of our knowledge is the first to investigate the potential interrelationship of leptin with fetal pulmonary development in a primate model.

Significant differences exist between humans and nonprimate species with respect to the endocrinology of pregnancy and the development of a functional maternalfetoplacental unit (Pepe \& Albrecht 1995). Therefore, in the current study we employed the baboon, a nonhuman primate that is an excellent model for human pregnancy with regard to both general gestational endocrinology (Castracane \& Goldzieher 1986, Henson 1998) and LEPrelated mechanisms (Henson et al. 1999, Green et al. 2000, O'Neil et al. 2001). Our primary objectives were to determine: (i) fetal serum leptin concentrations; (ii) leptin receptor ontogeny, via quantitative assessment of mRNA transcripts for leptin (LEP) in fetal lungs in early, mid and late pregnancy; (iii) the presence of leptin receptor protein in fetal pulmonary tissue; and (iv) the identities of specific cell types in fetal lung that express leptin receptor.

\section{Materials and Methods}

\section{Animals}

Animals were maintained and used in accordance with USDA regulations and the Guide for the Care and Use of Laboratory Animals (NIH Publication 86-23). The protocol was approved by the Institutional Care and Use Committee of the Tulane National Primate Research Center. Female baboons (Papio sp.) were quartered with males for mating in indoor/outdoor enclosures at the anticipated time of ovulation, as determined by daily menstrual cycle history and visible turgescence of external sex skin. Females were later housed individually in stainless steel cages, as we have previously described (Henson et al. 1999, Shi et al. 1999). Twelve-hour light photoperiods (0600-1800 h) were maintained in air-conditioned rooms and animals received a maintenance ration with fresh fruit daily and water freely available.

\section{Collection of tissues}

Lung tissue was obtained from fetal baboons upon cesarean delivery, under isofluorane anesthesia, after sedation with ketamine $\mathrm{HCl}$ /atropine, as we have previously described (Henson et al. 1999). Surgeries were performed early in gestation (days 58-62, $n=4$ ), at mid gestation (days $98-102, n=4$ ), or late in gestation (days 158-165, $n=4$ ) (term 184 days). Fetal blood samples were collected via cardiac puncture, prior to killing (sodium pentobarbital) and the collection of fetal lung tissue. Serum was separated by centrifugation $(1000 \mathrm{~g}, 10 \mathrm{~min})$ and frozen at $-20^{\circ} \mathrm{C}$ for RIA. Tissue was flash-frozen in liquid nitrogen and stored at $-70^{\circ} \mathrm{C}$, with random sections utilized for later RT-PCR and immunoblotting, or fixed in $10 \%$ formalin for immunohistochemistry.

\section{RNA extraction and RT-PCR}

Total RNA was extracted from tissues using TRIzol reagent (Invitrogen Life Technologies, Carlsbad, CA, USA), according to Chomczynski \& Sacchi (1987) and Chirgwin et al. (1979), as we have adapted for use in our laboratory (Henson et al. 1998, Shi et al. 1999). All samples were treated with DNase (Invitrogen) to eliminate DNA contamination and reprecipitated with sodium acetate and $100 \%$ ethanol. Oligonucleotide primers were synthesized (Midland Reagent Company, Midland, TX, USA) for leptin (Wabitsch et al. 1996), long (LEP- $\mathrm{R}_{\mathrm{L}}$ ) (Kielar et al. 1998) and short (LEP-RS) (Glasow et al. 1998) intracellular domain isoforms of the leptin receptor, and glyceraldehyde-3-phosphate dehydrogenase (GAPDH) (Henson et al. 1998). Sequence analysis of PCR products (Biotech Core, Palo Alto, CA, USA) confirmed that primers specifically amplified regions of leptin and leptin receptor cDNAs. cDNAs were synthesized from $2 \mu \mathrm{g}$ total RNA using the SuperScript kit (Invitrogen) and PCR was performed using HotStarTaq DNA Polymerase (Qiagen Inc., Valencia, CA, 
USA) in a GeneAmp PCR System 2400 (Perkin Elmer Applied Biosystems, Foster City, CA, USA) as we have described (Henson et al. 1998).

Conditions for PCR were adapted from Green et al. (2000) and O'Neil et al. (2001). They were as follows: LEP 30 cycles for amplification, denaturation at $94^{\circ} \mathrm{C}$ for $60 \mathrm{~s}$, annealing at $55^{\circ} \mathrm{C}$ for $30 \mathrm{~s}$, extension at $72{ }^{\circ} \mathrm{C}$ for $90 \mathrm{~s}$; LEP- $R_{S}, 30$ cycles for amplification, denaturation at $94^{\circ} \mathrm{C}$ for $30 \mathrm{~s}$, annealing at $51^{\circ} \mathrm{C}$ for $45 \mathrm{~s}$, extension at $72{ }^{\circ} \mathrm{C}$ for $30 \mathrm{~s}$; LEP-R $\mathrm{L}_{\mathrm{L}} 35$ cycles for amplification, denaturation at $94^{\circ} \mathrm{C}$ for $30 \mathrm{~s}$, annealing at $60^{\circ} \mathrm{C}$ for $30 \mathrm{~s}$, extension at $72{ }^{\circ} \mathrm{C}$ for $30 \mathrm{~s}$; GAPDH, 24 cycles for amplification, denaturation at $94{ }^{\circ} \mathrm{C}$ for $30 \mathrm{~s}$, annealing at $51^{\circ} \mathrm{C}$ for $45 \mathrm{~s}$, extension at $72^{\circ} \mathrm{C}$ for $30 \mathrm{~s}$. PCR products were visualized under u.v. light on $2 \%$ agarose gels with ethidium bromide. PCR reactions were accompanied by the following controls: GAPDH affirmed consistent cDNA synthesis, sterile water blanks served as a reagent control, and RNA that had not been transcribed into cDNA (absence of reverse transcriptase) was used as a control for DNA contamination, with no PCR products being evidenced in subsequent validation experiments. Following semiquantitative assessment of mRNA transcripts by comparison of PCR products with GAPDH, quantitative competitive RT-PCR was performed using the PCR MIMIC methodologies we have described (Henson et al. 1998, 1999). In this methodology, one set of primers is used to amplify both the target gene cDNA and the mimic, a nonhomologous DNA fragment engineered to contain specific target gene sequences necessary for recognition by the gene specific primers for the gene of interest. The mimic DNA competes with the target cDNA for the same primers, thereby serving as an internal standard. Products were resolved by $2 \%$ agarose gel electrophoresis, and band intensities analyzed using the Alpha Imager 2000 digital analysis system (Alpha Innotech, San Leandro, CA, USA). Concentrations were expressed as attomoles/ $\mu \mathrm{g}$ RNA ( 1 attomole $=6 \times 10^{5}$ molecules). All PCR experiments are subjected to replication, with the subsequent documentation of similar results required.

\section{Immunoblotting}

Total protein was extracted from fetal lung tissue using a homogenization buffer containing: $40 \mathrm{mmol} / / \mathrm{KH}_{2} \mathrm{PO}_{4}$, $10 \mathrm{mmol} / \mathrm{l}$ sucrose, $50 \mathrm{mmol} / \mathrm{l} \mathrm{KCl}, 30 \mathrm{mmol} / \mathrm{l}$ EDTA, $2 \mathrm{mmol} / \mathrm{l}$ EGTA, $25 \mu \mathrm{g} / \mathrm{ml}$ aprotinin, $25 \mu \mathrm{g} / \mathrm{ml}$ leupeptin and $1 \mathrm{mmol} / \mathrm{l}$ polymethylsulfonylfluoride. The tissue homogenate was then centrifuged, supernatant collected and protein concentration quantified according to Bradford (1976). Fifty micrograms of protein were denatured, reduced and then electrophoresed on a pre-cast $4-12 \%$ gradient Bis-Tris gel (Invitrogen), before transfer to nitrocellulose for immunoblot detection. Standards of known molecular mass (BioRad, Hercules, CA, USA) were run in adjacent lanes. Leptin receptor was detected with goat polyclonal anti-human leptin receptor (N-20; Santa Cruz
Biotechnology Inc., Santa Cruz, CA, USA) at a dilution of 1:500. This antibody detects the extracellular domain of the leptin receptor, i.e. both long $\left(\mathrm{LEP}-\mathrm{R}_{\mathrm{L}}\right.$ ) and short (LEP$R_{S}$ ) isoforms. A secondary antibody, donkey polyclonal anti-goat IgG, labeled with horseradish peroxidase (Santa Cruz) was then detected using the ECL Western blotting detection system (Amersham Pharmacia Biotech, Piscataway, NJ, USA) utilizing chemiluminescence film (HyperFilm; Amersham). A specific blocking peptide (Santa Cruz) for the leptin receptor antibody was used effectively as a control, successfully blocking the receptor signal.

\section{Immunohistochemistry}

Immunohistochemistry was performed according to the technique of Liu et al. (1997), as adapted for use in our laboratory. Fetal baboon lung was fixed in $10 \%$ buffered formalin, paraffin imbedded and $5 \mu \mathrm{m}$ sections cut. The sections were deparaffinized, antigen unmasked in citrate buffer and endogenous peroxidase activity quenched in $0.3 \%$ hydrogen peroxide diluted in methanol. Sections were then incubated in PBS, $0.2 \%$ fish skin gelatin (FSG) and $0.1 \%$ Triton X-100 for 20 min. Immunohistochemistry was facilitated using the Goat ABC Staining System (Santa Cruz) in a humidified chamber. Tissues were incubated in normal blocking serum for $1 \mathrm{~h}$, then incubated with primary antibody for either human leptin receptor $(\mathrm{Ob}-\mathrm{R}[\mathrm{N}-$ 20]; Santa Cruz) or pulmonary surfactant A (SP-A [N-19]; Santa (ruz) at a 1:25 dilution in normal blocking serum for $1 \mathrm{~h}$ at room temperature. Sections were again washed with PBS/FSG, then incubated with biotinylated secondary antibody. Sections were then washed with PBS/FSG then incubated with $A B$ enzyme reagent. Hybridization was then detected using peroxidase substrate. Sections were counter-stained using Gill's hematoxylin $(2 \times$ formulation $)$ and mounted. Controls included sections without: (i) primary antibody and (ii) primary and secondary antibody.

\section{RIA}

Leptin concentrations were determined by RIA (Diagnostic Systems Laboratories, Inc., Webster, TX, USA), employing an antibody against human leptin. Inter- and intraassay coefficients of variation $(n=5)$ for leptin were less than 9.0 and $5.0 \%$ respectively, with a sensitivity of $0.5 \mathrm{ng} / \mathrm{ml}$. The human assay had been previously validated for the baboon using a pregnant serum pool, for which serial dilutions yielded concentrations that were linear and parallel to those in human serum (Henson et al. 1999).

\section{Statistical analysis}

ANOVA, with standard post-hoc Student-Newman-Keuls tests, was employed using SigmaStat statistical analysis software, version 5.0 (SPSS, Richmond, CA, USA), to establish statistical significance between groups. Significant differences were understood to exist when $P<0.05$. 


\section{Results}

\section{Leptin and leptin receptor $m R N A$ transcripts}

Leptin mRNA transcripts were detected by RT-PCR in fetal lung tissue, although no apparent rise or fall in transcript abundance could be ascertained with advancing gestation (data not shown). However, leptin receptor transcript abundance (both long and short isoforms), as assessed by basic RT-PCR in respect to constitutively expressed GAPDH, appeared to increase dramatically in fetal lung tissue following mid gestation (Fig. 1). Indeed, as quantified by competitive RT-PCR and depicted in Fig. 2A, LEP- $\mathrm{R}_{\mathrm{L}}$ transcript abundance $(n=4)$ increased from $0.011 \pm 0.004$ attomoles $/ \mu$ g total RNA (mean \pm S.E.M.), in early gestation, to $0.017 \pm 0.004$ in mid gestation, to $0.119 \pm 0.013$ in late gestation. Therefore, although $L E P-R_{L}$ transcript abundance in early and mid gestation was quite low, approaching the level of nondetection, concentrations in late gestation were 10- and 7 -fold greater $(P<0.05)$ respectively. Overall, specific mRNA transcripts for LEP-R $R_{S}$ were of greater abundance than those for LEP- $\mathrm{R}_{\mathrm{L}}$, although a similar rate of increase was observed with respect to advancing gestation. Thus, as illustrated in Fig. 2B, LEP- $R_{S}$ transcript abundance $(n=4)$ increased from $0.069 \pm 0.028$ attomoles $/ \mu g$ total RNA in early gestation, to $0.139 \pm 0.032$ in mid gestation, to $0.550 \pm 0.057$ in late gestation. Therefore, LEP- $R_{S}$ transcript abundance in late gestation was approximately 4 -fold greater $(P<0.05)$ than at mid gestation and 8 -fold greater $(P<0.05)$ than in early gestation.

\section{A. LEP-R $(427$ bp)}

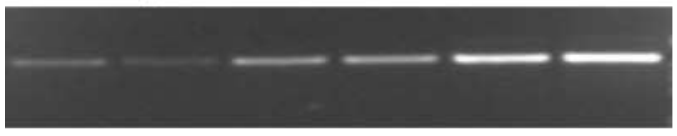

\section{B. LEP-R $(573$ bp)}

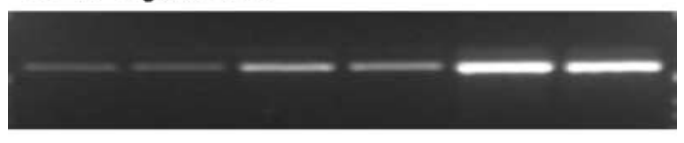

\section{GAPDH (240 bp)}

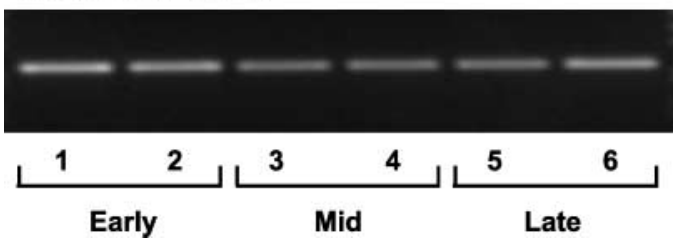

Figure 1 Representative expression of mRNA transcripts for LEP- $R_{L}$ (A) and LEP-R $(B)$ isoforms and GAPDH (C) in fetal lung tissues collected from two baboon fetuses in early (lanes 1 and 2) pregnancy, as well as in mid (lanes 3 and 4) and late (lanes 5 and 6) pregnancy.

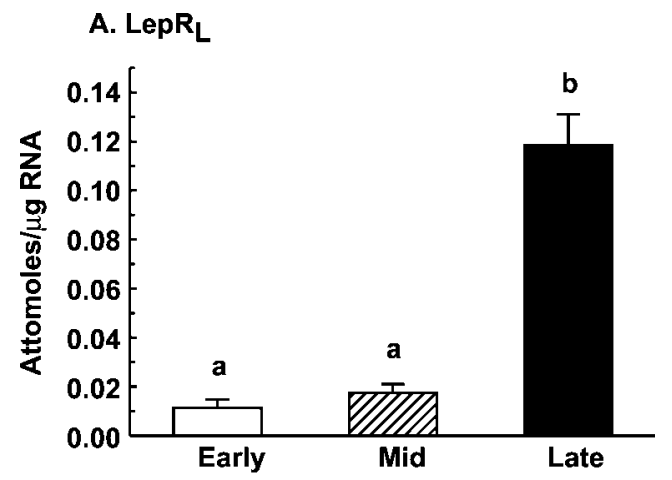

\section{B. LepRs}

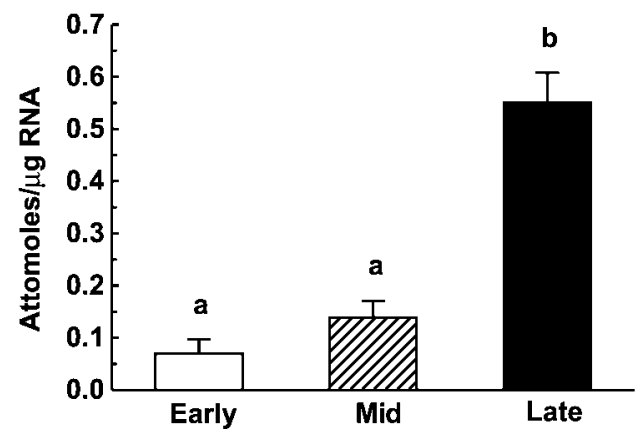

Figure 2 LEP- $R_{L}(A)$ and LEP- $R_{S}(B)$ mRNA transcript abundance, as determined by competitive RT-PCR in fetal lung tissues collected in early ( $n=4$ fetuses), mid ( $n=4$ fetuses), and late ( $n=4$ fetuses) baboon pregnancy. Different lowercase letters indicate significant differences between means ( $a b, P<0.01)$.

\section{Leptin receptor protein}

An immunoblot, which is representative of lung tissue collected from baboon fetuses at early $(n=2)$, mid $(n=2)$ and late $(n=2)$ gestation, appears as Fig. 3. Leptin receptor protein could not be detected by immunoblotting in fetal lungs collected in early and mid gestation, but was detected (approximately $130 \mathrm{kDa}$, as determined by molecular mass standards - not shown) in tissues collected in late gestation.

\section{Localization of leptin receptor in fetal lung}

As depicted in Fig. 4A-D, leptin receptor protein in lungs from late gestation fetuses was localized by immunohistochemistry in distal pulmonary epithelial cells, including type II cells (Fig. 4C). This cell type is known to actively

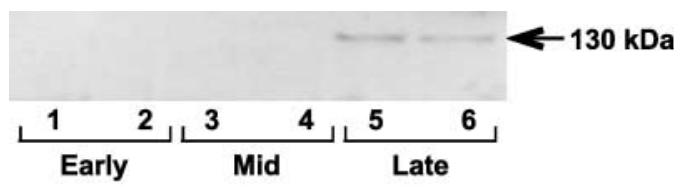

Figure 3 Excerpt from a representative immunoblot depicting relative LEP receptor abundance $(130 \mathrm{kDa})$ in fetal lung tissues collected in early ( $n=2$ fetuses, lanes 1 and 2$)$, mid ( $n=2$ fetuses, lanes 3 and $4)$, and late ( $n=2$ fetuses, lanes 5 and 6) baboon pregnancy. 


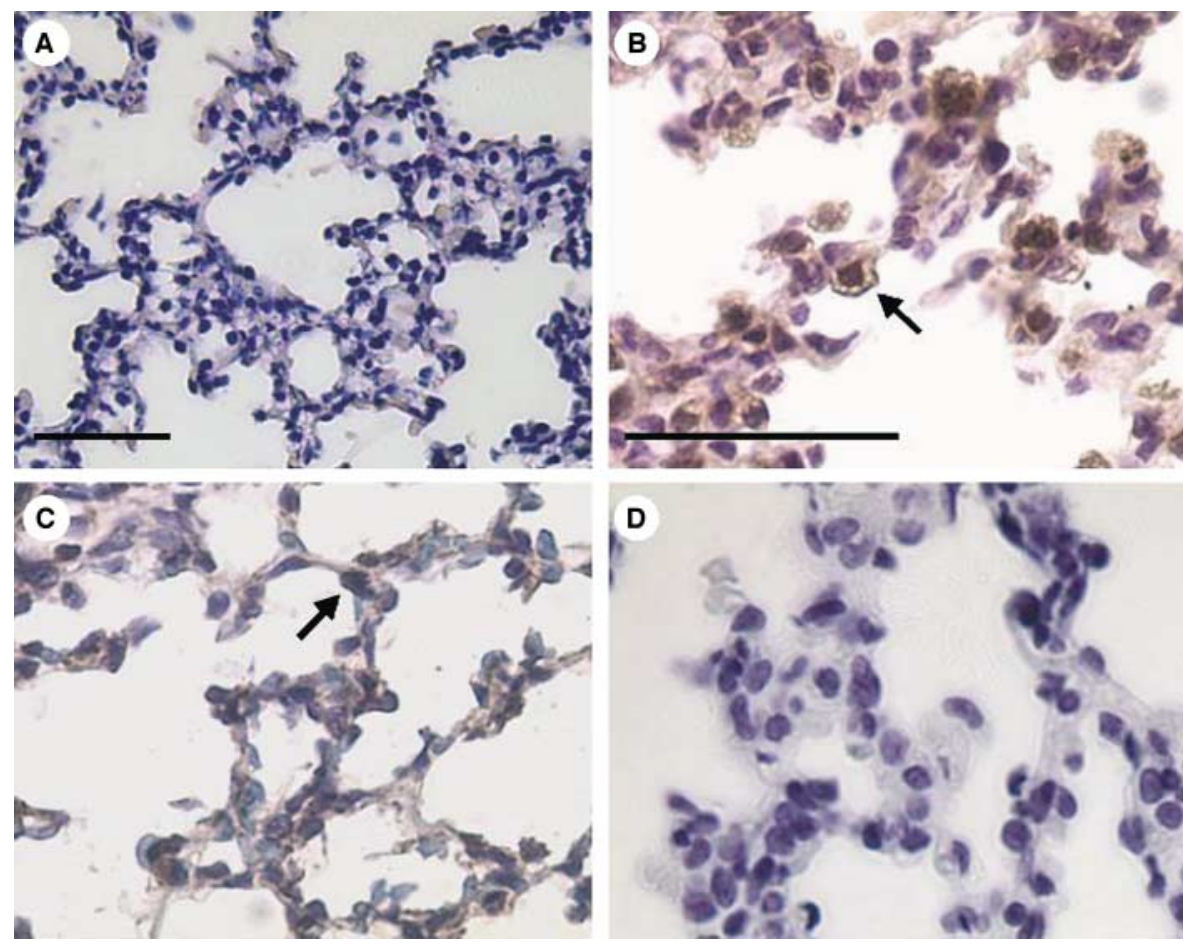

Figure 4 Photomicrographs of lung tissue from fetal baboons in late gestation depicting the results of $(A)$ hematoxylin-eosin staining $(\times 200)$ and immunohistochemical localization of (B) surfactant protein $A$ $(\times 400)$ or $(C)$ LEP receptor $(\times 400)$ protein in pulmonary epithelial cells. A negative (without primary antibody) immunohistochemical control for LEP receptor $(\times 400)$ is included $(D)$. Bars in panels $\mathrm{A}(\times 200)$ and $\mathrm{B}(\times 400)$ are $50 \mu \mathrm{m}$. Arrows denote pulmonary type II cells. produce pulmonary surfactant, as evidenced by specific immunohistochemical staining of surfactant protein A (Fig. 4B) in alternate sections.

\section{Fetal serum leptin concentrations}

Fetal serum leptin levels ranged from $5.7 \pm 1.1 \mathrm{ng} / \mathrm{ml}$ at mid gestation to $8.3 \pm 3.0 \mathrm{ng} / \mathrm{ml}$ in late gestation, concentrations that were not significantly different $(P>0.05)$ with respect to gestational age.

\section{Discussion}

The fetal lung develops the capacity for gas exchange relatively late in human pregnancy, as with increasing maturity surface tension declines at the alveolar air-liquid interface in response to the production of surfactant glycerophospholipids and proteins (Pepe \& Albrecht 1995). Fetal epithelial type II cells in the pulmonary alveoli produce this material, which is stored in lamellar bodies and then secreted into the air spaces via exocytosis. Although some type II cells are present in terminal alveolar sacs at mid gestation, the production of abundant surfactant does not begin until nearer term, a trait shared by humans with nonhuman primates (Feijen et al. 1979). Insufficient surfactant production commonly results in respiratory distress syndrome, a condition characterized by alveolar collapse, the overdistention of remaining compliant alveoli, pulmonary edema and focal pulmonary hemorrhages. It is a major cause of morbidity and mortality in premature infants ( $<32$ weeks gestation, $<1200$ g body weight). The maturation of type II cells, along with their potential to produce adequate surfactant, is principally regulated by the enhanced concentration of fetal cortisol inherent at term, a mechanism that in cases of impending premature delivery can be elicited by the administration of synthetic glucocorticoids.

In addition to the effects of cortisol, an array of growth factors, including transforming growth factor- $\beta 3$, epithelial growth factor, tumor necrosis factor and vasointestinal peptide are involved in pulmonary development (Bolt et al. 2001). Indeed, in fetal baboons in which cortisol levels were suppressed in utero via estrogen deprivation, lung maturation proceeded unabated, suggesting the need for further studies to identify and characterize associated regulatory factors (Pepe et al. 2003). Therefore, although it is known that the maturation of type II cells is modulated by a number of soluble, low molecular weight peptides, the identity of a specific fibroblast pneumocyte factor (FPF) remains elusive. This protein is proposed to be induced by glucocorticoids, promote surfactant production, and be down-regulated by androgens (Torday et al. 2002). A number of potential commonalities exist between leptin and this putative modulator. Thus, it is interesting to note that lung development in male fetuses is somewhat delayed when compared with females in a variety of species, a phenomenon that reflects an inhibition by androgens (Provost et al. 2002). This relationship is mirrored by a similar androgen inhibition of leptin biosynthesis, an effect that is definitively linked to gender (Casabiell et al. 2001, Morash et al. 2001). Other regulatory parallels include the effects of glucocorticoids, which in addition to up-regulating the putative FPF in the lung (Bolt et al. 2001), increase leptin synthesis and release by human adipocytes (Leal-Cerro et al. 2001), and enhance leptin levels in preterm infants 
( $\mathrm{Ng}$ et al. 2002). Moreover, the co-culture of human placental trophoblast cells with glucocorticoids has been observed to enhance leptin release (Coya et al. 2001), while maternal glucocorticoid treatment resulted in an up-regulation of placental leptin receptor protein in rat pregnancy (Sugden et al. 2001). Therefore, with respect to: (i) the effects of androgens and glucocorticoids; (ii) the common tissues of origin of both leptin and the putative regulator; and (iii) the similarities in the molecular masses of leptin and the proposed FPF (Bergen et al. 2002, Torday \& Rehan 2002), leptin has been suggested by Torday et al. (2002) as a logical FPF candidate.

Fetal leptin, originating in the placental trophoblast (Chen et al. 2000) or in fetal adipose tissues (Lepercq et al. 2001), is firmly associated with conceptus growth and development in a number of species, including humans (Bajoria et al. 2002, Henson \& Castracane 2002, 2003, Sagawa et al. 2002). Effects are mediated in a variety of tissues via a specific leptin receptor, which is a member of the cytokine class I receptor superfamily. It exists as multiple alternatively spliced isoforms, each differing in the length of their intracellular domains (Tartaglia 1997). The long isoform (LEP-R $\mathrm{L}_{\mathrm{L}}$ ) is detected in various tissues, but is predominant in the hypothalamus, where it functions in the regulation of satiety and is capable of signal transduction through the activation of Janus kinase and the signal transducers and activators of transcription. A shorter isoform $\left(L E P-R_{S}\right)$ is predominant in peripheral tissues such as the lung and, as reported by Bjorbaek et al. (1997, 2001), contributes to leptin signaling via mitogen-activated protein kinase. In the present study, we have determined the ontogeny of leptin receptor in fetal lung during pregnancy in the baboon, a species that is a proven investigational model for the endocrinology of human pregnancy (Castracane \& Goldzieher 1986, Pepe \& Albrecht 1995, Henson 1998), as well as for fetal (Kotas \& Kling 1979, Coalson et al. 1998, Pepe et al. 2003) and neonatal (Janssen et al. 2002) lung maturation. Indeed, the choice of model may be of even greater importance with respect to those mechanisms specifically linked to leptin dynamics, as significant differences in leptin and leptin receptor regulation may exist in pregnancy-associated tissues (fetus, placenta, amniochorion, decidua, etc.) in primates (human and nonhuman) vs those in nonprimate species (Henson \& Castracane 2000, 2002 2003, Bajoria et al. 2002, Sagawa et al. 2002).

With regard to the potential for leptin to modulate pulmonary development and function, cumulative evidence identifies both fetal and adult lungs as leptin-responsive tissues (Chen et al. 1996, Hoggard et al. 1997, Tsuchiya et al. 1999, Dal Farra et al. 2000), and clearly implies roles for the polypeptide in helping to stimulate pulmonary cell proliferation (Tsuchiya et al. 1999) and enhancing stretch-induced surfactant production (Torday \& Rehan 2002, Torday et al. 2002, Vlahakis \& Hubmayr 2003). In evidence of these effects, genetically obese $(o b / o b)$ mice are unable to produce leptin, but are exposed to leptin in utero by virtue of their propagation in $+/+$ or $o b /+$ (leptin-sufficient) dams. However, following birth, lung volume and pulmonary compliance in neonates became attenuated if not supplemented with exogenous leptin (Tankersley et al. 1998). With respect to mice that were leptin receptor deficient due to genetic mutation, Tsuchiya et al. (1999) reported that the rate of tracheal epithelial cell proliferation was only one-quarter $(P<0.01)$ that of their unaffected littermates, illustrating a potentially important supplementary role for leptin in pulmonary development. Other studies further suggest a significant impact of leptin on general pulmonary health in rodents (O'Donnell et al. 1999), as well as on specific respiratory disorders in humans (O'Donnell et al. 2000). Intriguingly, obesity-related respiratory anomalies are characteristically exacerbated in males (Kapsimalis \& Kryger 2002), perhaps reflecting again the gender dichotomy that is typical with respect to circulating leptin concentrations (Casabiell et al. 2001).

In conclusion, we have reported that leptin originating in the placental trophoblast and/or fetal adipose tissue exists in significant concentrations in the circulation of the fetal baboon, attesting to its physiological availability. Although we previously determined that leptin receptor transcripts in both the placental trophoblast and maternal adipose tissues were constitutively expressed throughout baboon pregnancy (Green et al. 2000), our current findings indicate a significant divergence with respect to fetal lung. Thus, transcripts for two isoforms of the leptin receptor were ontogenetically up-regulated in fetal pulmonary tissue with advancing gestation, an effect that was mirrored by the synthesis of leptin receptor protein near term. Immunoblotting of leptin receptor revealed a protein of approximately $130 \mathrm{kDa}$, similar to that previously reported in other species (Hoggard et al. 1997, Tartaglia 1997, Bergen et al. 2002). Although the determination of a specific cause and effect relationship was beyond the scope of the present study, leptin receptor expression was observed largely in type II epithelial cells, which are responsible for the production of pulmonary surfactant. These constitute the first such observations in a primate. Ontogenetic regulation of the receptor may suggest a role for the polypeptide in modulating general pulmonary development or optimizing surfactant production, and/or may identify leptin receptor as a physiological marker of primate fetal lung maturity.

\section{Acknowledgements}

We gratefully acknowledge Dr April G O'Quinn, Chair of the Department of Obstetrics and Gynecology, Tulane University Health Sciences Center, and P51 RR00164, for support, and Mrs Nathlynn Dellande for her assistance with figure design and manuscript preparation.

This work was supported by the Department of Obstetrics and Gynecology, and by NIH grant P51 RR00164 and the Tulane National Primate Research Center, Tulane University 
Health Sciences Center. Presented at the 50th Annual Meeting of the Society for Gynecologic Investigation, March 2630 2003, Washington, DC, USA.

\section{References}

Ahima RS \& Flier JS 2000 Leptin. Annual Review of Physiology 62 413-437.

Bajoria R, Sooranna SR, Ward BS \& Chatterjee R 2002 Prospective function of placental leptin at maternal-fetal interface. Placenta 23 103-115.

Bergen HT, Cherlet TC, Manuel P \& Scott JE 2002 Identification of leptin receptors in lung and isolated fetal type II cells. American Journal of Respiratory Cell and Molecular Biology 27 71-77.

Bjorbaek C, Uotani S, da Silva B \& Flier JS 1997 Divergent signaling capacities of the long and short isoforms of the leptin receptor. Journal of Biological Chemistry 272 32686-32695.

Bjorbaek C, Buchholz RM, Davis SM, Bates SH, Pierroz DD, Gu H et al. 2001 Divergent roles of SHP-2 in ERK activation by leptin receptors. Journal of Biological Chemistry 276 4747-4755.

Bolt RJ, van Weissenbruch MM, Lafeber HN \& Delemarre-van de Waal HA 2001 Glucocorticoids and lung development in the fetus and preterm infant. Pediatric Pulmonology 32 76-91.

Bradford MM 1976 A rapid and sensitive method for the quantitation of microgram quantities of protein utilizing the principle of protein-dye binding. Analytical Biochemistry 72 248-254.

Casabiell X, Pineiro V, Vega F, De La Cruz LF, Dieguez C \& Casanueva FF 2001 Leptin, reproduction and sex steroids. Pituitary 4 93-99.

Castracane VD \& Goldzieher JW 1986 Timing of the luteal-placental shift in the baboon (Papio cynocephalus). Endocrinology 118 506-512.

Chen H, Charlat O, Tartaglia LA, Woolf EA, Weng X, Ellis SJ et al. 1996 Evidence that the diabetes gene encodes the leptin receptor: identification of a mutation in the leptin receptor gene in $d b / d b$ mice. Cell 84 491-495.

Chen X, Lin J, Hausman DB, Martin RJ, Dean RG \& Hausman GJ 2000 Alterations in fetal adipose tissue leptin expression correlate with the development of adipose tissue. Biology of the Neonate $\mathbf{7 8}$ $41-47$.

Chirgwin JM, Przybyla AE, MacDonald RJ \& Rutter WJ 1979 Isolation of biologically active ribonucleic acid from sources enriched in ribonuclease. Biochemistry 18 5294-5299.

Chomczynski P \& Sacchi N 1987 Single-step method of RNA isolation by acid guanidinium thiocyanate-phenol-chloroform extraction. Analytical Biochemistry 162 156-159.

Coalson JJ, Winter V \& Yang F 1998 Site specificity of surfactant protein expression in airways of baboons during gestation. Anatomical Record 250 300-315.

Coya R, Gualillo O, Pineda J, Garcia MC, Busturia MA, Aniel-Quiroga A et al. 2001 Effect of cyclic 3'-5'-adenosine monophosphate, glucocorticoids, and insulin on leptin messenger RNA levels and leptin secretion in cultured human trophoblast. Biology of Reproduction 65 814-819.

Dal Farra C, Zsurger N, Vincent JP \& Cupo A 2000 Binding of a pure ${ }^{125}$ I-monoiodoleptin analog to mouse tissues: a developmental study. Peptides 21 577-587.

Feijen HW, de Haan J, Martin CB Jr, Nederstigt J \& Houx PC 1979 The lecithin/sphingomyelin ratio in Macaca arctoides. Gynecologic and Obstetric Investigation 10 186-192.

Friedman JM \& Halaas JL 1998 Leptin and the regulation of body weight in mammals. Nature $395763-770$.

Glasow A, Haidan A, Hilbers U, Breidert M, Gillespie J, Scherbaum WA et al. 1998 Expression of $O b$ receptor in normal human adrenals: differential regulation of adrenocortical and adrenomedullary function by leptin. Journal of Clinical Endocrinology and Metabolism 83 4459-4466.
Green AE, O'Neil JS, Swan KF, Bohm RP Jr, Ratterree MS \& Henson MC 2000 Leptin receptor transcripts are constitutively expressed in placenta and adipose tissue with advancing baboon pregnancy. Proceedings of the Society for Experimental Biology and Medicine 223 362-366.

Henson MC 1998 Pregnancy maintenance and the regulation of placental progesterone biosynthesis in the baboon. Human Reproduction Update 4 389-405.

Henson MC \& Castracane VD 2000 Leptin in pregnancy. Biology of Reproduction 63 1219-1228.

Henson MC \& Castracane VD 2002 Leptin: roles and regulation in primate pregnancy. Seminars in Reproductive Medicine $\mathbf{2 0}$ $113-122$.

Henson MC \& Castracane VD 2003 Leptin in primate pregnancy. In Leptin and Reproduction, pp 239-263. Eds MC Henson \& VD Castracane. New York: Kluwer Academic/Plenum Publishers.

Henson MC, Swan KF \& O'Neil JS 1998 Expression of placental leptin and leptin receptor transcripts in early pregnancy and at term. Obstetrics and Gynecology 92 1020-1028.

Henson MC, Castracane VD, O'Neil JS, Gimpel T, Swan KF, Green AE et al. 1999 Serum leptin concentrations and expression of leptin transcripts in placental trophoblast with advancing baboon pregnancy. Journal of Clinical Endocrinology and Metabolism $\mathbf{8 4}$ $2543-2549$.

Hoggard N, Hunter L, Duncan JS, Williams LM, Trayhurn P \& Mercer JG 1997 Leptin and leptin receptor mRNA and protein expression in the murine fetus and placenta. PNAS $\mathbf{9 4}$ 11073-11078.

Janssen DJMT, Carnielli VP, Cogo PE, Seidner SR, Luijendijk IHI, Wattimena JLD et al. 2002 Surfactant phosphatidylcholine half-life and pool size measurements in premature baboons developing bronchopulmonary dysplasia. Pediatric Research 52 724-729.

Kapsimalis F \& Kryger MH 2002 Gender and obstructive sleep apnea, part 2: mechanisms. Sleep 25 499-506.

Kielar D, Clark JSC, Ciechanowicz A, Kurzawski G, Sulikowski T \& Naruszewicz M 1998 Leptin receptor isoforms expressed in human adipose tissue. Metabolism 47 844-847.

Kotas RV \& Kling OR 1979 Influence of glucocorticoid administration and inhibition of fetal baboon pulmonary maturity and the amniotic fluid L/S ratio. Journal of Medical Primatology 8 88-94.

Leal-Cerro A, Soto A, Martinez MA, Dieguez C \& Casanueva FF 2001 Influence of cortisol status on leptin secretion. Pituitary 4 $111-116$.

Lepercq J, Challier J-C, Guerre-Millo M, Cauzac M, Vidal H \& Hauguel-de Mouzon S 2001 Prenatal leptin production: evidence that fetal adipose tissue produces leptin. Journal of Clinical Endocrinology and Metabolism 86 2409-2413.

Liu J-Y, Morris GF, Lei W-H, Hart CE, Lasky JA \& Brody AR 1997 Rapid activation of PDGF-A and BB expression at sites of lung injury in asbestos-exposed rats. American Journal of Respiratory Cell and Molecular Biology 17 129-140.

Morash BA, Ur E \& Wilkinson M 2001 Pituitary leptin gene expression is reduced by neonatal androgenization of female rats. Pituitary 4 63-70.

Ng PC, Lam CW, Lee CH, Fok TF, Chan IH, Ma KC et al. 2002 Changes in serum leptin concentration after corticosteroid treatment in preterm infants. Acta Paediatrica 91 684-690.

O'Donnell CP, Schaub CD, Haines AS, Berkowitz DE, Tankersley CG, Schwartz AR et al. 1999 Leptin prevents respiratory depression in obesity. American Journal of Respiratory and Critical Care Medicine 159 1477-1484.

O'Donnell CP, Tankersley CG, Polotsky VP, Schwartz AR \& Smith PL 2000 Leptin, obesity, and respiratory function. Respiratory Physiology 119 163-170.

O'Neil JS, Green AE, Edwards DE, Swan KF, Gimpel T, Castracane VD et al. 2001 Regulation of leptin and leptin receptor in baboon pregnancy: effects of advancing gestation and fetectomy. Journal of Clinical Endocrinology and Metabolism 86 2518-2524. 
Pepe GJ \& Albrecht ED 1995 Actions of placental and fetal adrenal steroid hormones in primate pregnancy. Endocrine Reviews 16 608-648.

Pepe GJ, Ballard PL \& Albrecht ED 2003 Fetal lung maturation in estrogen-deprived baboons. Journal of Clinical Endocrinology and Metabolism $88471-477$.

Provost PR, Blomquist CH, Drolet R, Flamand N \& Tremblay Y 2002 Androgen inactivation in human lung fibroblasts: variation in levels of $17 \beta$-hydroxysteroid dehydrogenase type 2 and 5 alphareductase activity compatible with androgen inactivation. Journal of Clinical Endocrinology and Metabolism 87 3883-3892.

Sagawa N, Yura S, Itoh H, Mise H, Kakui K, Korita D et al. 2002 Role of leptin in pregnancy - a review. Placenta 23 (Suppl 1) S80-S86.

Shi W, Swan KF, Lear SR, O'Neil JS, Erickson SK \& Henson MC 1999 Regulation of pathways determining cholesterol availability in the baboon placenta with advancing gestation. Biology of Reproduction 61 1499-1505.

Sugden MC, Langdown ML, Munns MJ \& Holness MJ 2001 Maternal glucocorticoid treatment modulates placental leptin and leptin receptor expression and materno-fetal leptin physiology during late pregnancy, and elicits hypertension associated with hyperleptinaemia in the early-growth-retarded adult offspring. European Journal of Endocrinology 145 529-539.

Tankersley CG, O'Donnell C, Daood MJ, Watchko JF, Mitzner W, Schwartz A et al. 1998 Leptin attenuates respiratory complications associated with the obese phenotype. Journal of Applied Physiology $852261-2269$.
Tartaglia LA 1997 The leptin receptor. Journal of Biological Chemistry 272 6093-6096.

Torday JS \& Rehan VK 2002 Stretch-stimulated surfactant synthesis is coordinated by the paracrine actions of PTHrP and leptin. American Journal of Physiology. Lung Cellular and Molecular Physiology 283 L130-L135.

Torday JS, Sun H, Wang L, Torres E, Sunday ME \& Rubin LP 2002 Leptin mediates the parathyroid hormone-related protein paracrine stimulation of fetal lung maturation. American Journal of Physiology. Lung Cellular and Molecular Physiology 282 L405-L410.

Tsuchiya T, Shimizu H, Horie T \& Mori M 1999 Expression of leptin receptor in lung: leptin as a growth factor. European Journal of Pharmacology 365 273-279.

Vlahakis NE \& Hubmayr RD 2003 Response of alveolar cells to mechanical stress. Current Opinion in Critical Care 9 2-8.

Wabitsch M, Jensen PB, Blum WF, Christoffersen CT, Englaro P, Heinze $\mathbf{E}$ et al. 1996 Insulin and cortisol promote leptin production in cultured human fat cells. Diabetes $\mathbf{4 5}$ 1435-1438.

Received 26 August 2003

First decision 12 September 2003

Accepted 25 September 2003 